\title{
TRIPOGON (GRAMINEAE) IN THAILAND
}

\author{
J.F. VELDKAMP ${ }^{1} \&$ S.M. PHILLIPS ${ }^{2}$
}

\begin{abstract}
SUMMARY
Survey with key of the 4 species of Tripogon (Gramineae) of Thailand with an emended description of $T$. thorelii.
\end{abstract}

Key words: Gramineae, Tripogon, Thailand.

Recently a few hundred grass specimens, collected in various parts of Thailand under the supervision of Dr. S. Laegaard (AAU) and Dr. W.J.J.O. de Wilde \& Dr. B.E.E. de Wilde-Duyfjes (L), were presented to JFV for identification.

Among these was a curious representative of Tripogon Roem. \& Schult. At first it seemed an undescribed species, but it turned out to be identical with T. thorelii A. Camus, so far only known from the type, possibly collected in Laos. A search in the herbaria of $\mathrm{K}$ and $\mathrm{L}$ turned up 3 additional specimens from which an emended description could be made.

\section{Tripogon thorelii A. Camus}

Tripogon thorelii A. Camus (1920) 14; (1923) 534. - Type: Thorel 2479 (holo P, photo K, fragm. in L; iso P), ? Laos, 'Kouy' ('Kong').

Densely tufted perennials. Culms $30-80 \mathrm{~cm}$ long. Sheaths glabrous, shoulders with an up to $3.5 \mathrm{~mm}$ long arachnoid tuft of hairs on both sides, the basal ones tardily withering into fibres. Ligule a ciliolate rim. Blades articulating at base, straight, erect, filiform, $8-28 \mathrm{~cm}$ by $0.5-0.8 \mathrm{~mm}$. Racemes rather to very lax, straight, $7.5-50 \mathrm{~cm}$ or more long. Spikelets imbricate to distant, 4.5-12 $\mathrm{mm}$ long (without the awns), 2-12-flowered, green to greenish purple. Lower glume 1.7-2.5 mm long, acute, with a lateral lobe; upper glume 3-3.8 mm long. First and second lemma bisexual, paleate, lanceolate in profile, body 2.7-3.2 mm long, apex obtuse to 2-dentate, teeth acute, up to $0.3 \mathrm{~mm}$ long, not extended into awnlets, central awn straight, 1-2.2 mm long, shorter than lemma body. Palea winged on the keels, wing margins ciliate. Anthers 3, c. $1.2 \mathrm{~mm}$ long.

Distribution - ? Laos: Kong ('Kouy'), see notes. E Thailand: Sisaket, Dongrak Range at Chong Bat Lak; Ubon Ratchathani: Kang Tana National Park.

1) Nationaal Herbarium Nederland, Universiteit Leiden branch, P.O. Box 9514, 2300 RA Leiden, The Netherlands; e-mail: veldkamp@nhn.leidenuniv.nl

2) Herbarium, Royal Botanic Gardens, Kew, Richmond, Surrey TW9 3AB, United Kingdom;

e-mail: s.phillips@kew.org 
Habitat - Exposed rocky place, on sandstone bedrock savannah, common to scattered in deciduous dipterocarp forest, 120-650 m altitude.

Collector's notes - Tussocks. Erect. Inflorescences brown-green. Glumes green.

Notes - This species is especially remarkable for the tufts of spidery hairs on the shoulders of the sheath at both ends of the very small ligule, and the very long narrow inflorescences, which at first sight are so similar to the leaves that the fact that the plant is flowering is easily overlooked.

There are some errors in dimensions in Camus' descriptions, and the locus typicus would be 'Kong', not 'Kouy', according to a note on the isotype in $\mathrm{P}$ and the correction in Camus (1923).

In the search for the identity of the specimens, the 3 other similarly robust species occurring in Thailand were studied as well.

The main distinguishing characters of these 4 species are set out in the following key:

1a. Leaf sheaths with dense woolly hairs on the shoulders. Lower glume $1.7-2.5 \mathrm{~mm}$ long. - First and second lemma bisexual, paleate; central awn 1-3 mm long, lateral

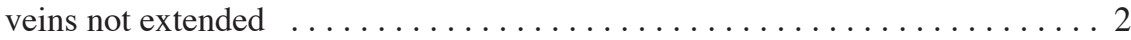

b. Leaf sheaths glabrous on the shoulders or with a few straight hairs. Lower glume 2.4-5 mm long. - Blades articulating at base, involute, $1.2-1.5 \mathrm{~mm}$ wide . . 3

2a. Leaf blades much shorter than the racemes, not articulating at base, flat, c. $3 \mathrm{~mm}$ wide. Spikelets $12-15 \mathrm{~mm}$ long (without the awns), imbricate by c. $2 / 3$ their length, diverging from raceme axis. Upper glume c. $5 \mathrm{~mm}$ long. Lemmas broadly lanceolate . . . . . . . . . . . . . . . . . . . . . . . . . . . .

b. Leaf blades extending up among racemes, articulating at base, involute, $0.5-0.8$ $\mathrm{mm}$ wide. Spikelets $4.5-12 \mathrm{~mm}$ long (without the awns), imbricate by c. $1 / 3$ their length or less, appressed to raceme axis. Upper glume 3-3.8 mm long. Lemmas

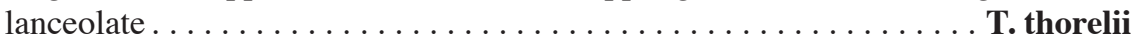

3a. First lemma sterile, epaleate; second lemma bisexual, paleate, 2-dentate, lateral veins extended into $0.1-0.2 \mathrm{~mm}$ long mucros; central awn $1.8-2.4 \mathrm{~mm}$ long ...

T. siamensis

b. First and second lemma bisexual, paleate, 2-cleft, lateral veins extended into $0.4-1.5$ mm awnlets; central awn $4.5-11 \mathrm{~mm}$ long . . . . . . . . . . trifidus

\section{Tripogon larsenii Bor}

Tripogon larsenii Bor (1968) 470. - Type: Larsen, Smitinand \& Warncke 1012 (holo AAU; iso K), N Thailand, Phitsanulok, Puh Mieng Mt.

Culms 30-60 cm tall. Leaf sheaths with up to $6 \mathrm{~mm}$ long woolly hairs on the shoulders, the basal ones withering into fibres. Blades linear, flat, tough, rigid, not articulating at base, up to $21 \mathrm{~cm}$ by c. $3 \mathrm{~mm}$. Spikelets imbricate by c. $2 / 3$ their length except at raceme base, 12-15 mm long, 11-13-flowered. Lower glume c. $2.5 \mathrm{~mm}$ long, with a lateral lobe; upper glume c. $5 \mathrm{~mm}$ long. First and subsequent lemmas bisexual, paleate, broadly lanceolate in profile, body c. $3.5 \mathrm{~mm}$ long, apex 2-dentate, lateral veins not extended into awnlets; central awn 1.4-2.3 mm long. 
Distribution - Known only from the type.

Habitat - Open sandstone plateau in moss; c. $1300 \mathrm{~m}$ altitude.

\section{Tripogon siamensis Bor}

Tripogon siamensis Bor (1963) 14, t. 3. - Type: Smitinand 6074 (holo K), NE Thailand, Loei, Phu Kradeng.

Culms up to $45 \mathrm{~cm}$ tall. Leaf sheaths without woolly hair tufts on the shoulders, a few long hairs at the mouth, the basal ones tardily withering into fibres. Blades filiform, involute, articulating at base, up to $25 \mathrm{~cm}$ by c. $1.5 \mathrm{~mm}$. Racemes lax, up to $25 \mathrm{~cm}$ long. Spikelets imbricate to distant, 10-15 mm long, 8-14-flowered. Lower glume c. $5 \mathrm{~mm}$ long, lobed on one side; upper glume c. $4.5 \mathrm{~mm}$ long. First lemma sterile, epaleate, c. $3.75 \mathrm{~mm}$ long, acute or emarginate, mucronate to shortly awned; subsequent lemmas bisexual, paleate, narrowly lanceolate in profile, body 3.5-3.7 mm long, apex 2-dentate, lateral veins not extended into awnlets; awn 1.8-2.4 mm long.

Distribution - Known only from the type.

Habitat - Common on rocky ground along edge of evergreen forest; c. $1300 \mathrm{~m}$ altitude.

Collector's notes - Large tufted grass. Glumes purple.

\section{Tripogon trifidus Munro ex Stapf}

Tripogon trifidus Munro ex Stapf [(1892) 85, nomen] (1896) 286. - Lectotype: Griffith Herb. E Ind. Comp. KD 6634 (holo K; L), India, Meghalaya, Khasia, designated by Noltie (1999: 394).

Culms 30-50 cm tall. Sheaths with glabrous shoulders or with some straight hairs at the mouth, the basal ones finally withering into fibres. Blades filiform, involute, rarely flat, articulating at base, $24-30 \mathrm{~cm}$ by $1.2-1.5 \mathrm{~mm}$. Racemes lax, $10-20 \mathrm{~cm}$ long. Spikelets loosely to densely imbricate, 7-14 mm long, 5-13-flowered. Lower glume lobed on one side, 2.4-4.2 mm long; upper glume 4-6.5 mm long. First and subsequent lemmas bisexual, paleate, lanceolate in profile, body $2.6-4 \mathrm{~mm}$ long, apex 2-cleft, lateral veins extended as $0.4-1.5 \mathrm{~mm}$ awnlets; central awn 4.5-11 $\mathrm{mm}$ long.

Distribution - Widespread in SE Asia, ranging from Nepal (Lower Langtang valley, G.\& S. Miehe 10385, K), Bhutan, China (Tibet) to Vietnam. Thailand: North: Chiangmai, Doi Inthanon, Chiang Doi Hills. East: Nakhon Ratchasima, Khao Yai National Park; see note.

Habitat - Stony ground, among rocks, in the open or in shade of broad-leaved mountain forest, trailsides, in or near rivers, waterfalls (possibly a rheophyte?); altitude $600-2650 \mathrm{~m}$.

Note - Larsen et al. 31828 (K, L; AAU n.v.) from $15 \mathrm{~km} \mathrm{NE}$ of Chaiyaphum may belong here. The spikelets are very young, but the lemmas have awned lateral lobes and the central awn is longer than the body.

\section{ACKNOWLEDGEMENTS}

Thanks are due to Dr. T. Deroin (P) to make the holo- and isotype of T. thorelii available to JFV on short notice. 


\section{REFERENCES}

Bor, N.L. 1963. New Asiatic grasses. Maheshwari Comm. Vol., J. Indian Soc. 42-A: 14, t. 3.

Bor, N.L. 1968. Gramineae. Some new taxa. Dansk Bot. Ark. 68: 470.

Camus, A. 1920. Un Tripogon nouveau d'Asie orientale. Notul. Syst. (Paris) 4: 14.

Camus, A. 1923. Flore générale de l'Indo-Chine 7: 534.

Noltie, H.J. 1999. Notes relating to the flora of Bhutan: XXXIX. Gramineae II. Edinburgh J. Bot. 56: 394.

Stapf, O. 1892. Decades kewenses. Bull. Misc. Inform.: 85.

Stapf, O. 1896. In: J.D. Hooker, Flora of British India 7: 286. Reeve \& Co., Brook nr. Ashford.

\section{IDENTIFICATION LIST}
lar $=$ Tripogon larsenii Bor
tho $=$ Tripogon thorelii $\mathrm{A}$. Camus
sia $=$ Tripogon siamensis Bor
tri $=$ Tripogon trifidus Munro ex Stapf

BKF 51791 (Smitinand 11675): tho.

Kerr 6694: tri.

Laegaard 21594: tri; 21650: tri; 21668: tri; 21730: tri - Larsen et al. 31828: ?tri - Larsen, Smitinand \& Warncke 1012 (T): lar.

Maxwell 76-518: tho.

Phengkhlai 476: tri - Pooma et al. 2375: tho.

Smitinand 6074 (T): sia.

Thorel 2479 (T): tho.

Van Beusekom \& Charoenpol 1831: tri. 